\title{
Uneasy Discipline: training workers after Fordism in Turkey and Argentina ${ }^{1}$
}

Fulya Apaydin, Institut Barcelona d'Estudis Internacionals

\begin{abstract}
Contemporary capitalism is marked by a disciplinary revolution. Thanks to the diffusion of just-in-time, flexible production systems, new techniques that impose a new form of discipline are increasingly common across many workplaces. This is conceptually distinct from the Fordist disciplinary regime organized around a swift punishing of worker disobedience. Through a comparison of two factories of the same company located in Turkey and Argentina, this article shows that political dynamics play a central role in this process.
\end{abstract}

Fulya Apaydin is AXA Research Fund Postdoctoral Fellow at Institut Barcelona d'Estudis Internacionals, Barcelona, Spain. She is especially interested in why states prioritize the development of some economic sectors over others. Part of Fulya's work looks at the transformative impact of new manufacturing technologies in Turkey and Argentina. Her current project explores the rise of Islamic finance in non-Western settings. Email: fapaydin@ibei.org

Keywords: Turkey, Argentina, Worker-training, Neoliberalism, Global South

\section{Introduction}

Contemporary capitalism is marked by a disciplinary revolution. Over the last three decades, new disciplinary techniques without immediate punishment were systematically put into practice across many workplaces. This new regime is conceptually distinct from the previous 
one because it is characterized by the growing prominence of behavioral tactics that nudge workers to comply with manager directives. This process was initiated by the global diffusion of just-in-time, flexible production as practiced by the Toyota Corporation. Since the early 1990s, most businesses adopted techniques inspired by Toyotism with the goal of generating permanent modifications in worker behavior. While technical training is emphasized as an indispensable part of human capital formation, the new priority is on modules that are geared to create an obedient work force. Using these technologies, the management can identify and detect "problem-workers", and take action before a potentially disruptive collective action occurs. The broader goal is to have a smooth and profitable surplus extraction that is also easier to manage.

However, the process of consolidating this new disciplinary regime under neoliberalism is riddled with conflict. This article reveals that the outcome of exchanges between business and labour is largely contingent on political dynamics that surround the world of work. For example, if an existing strife between business and labour is couched in a broader political conflict, embedding institutions necessary for consolidating a neoliberal worker profile is difficult. Under these circumstances, disciplinary actions vis-à-vis unruly employees will be characterized by the use of immediate punishment such as pay reductions, dismissals and even the use of force to repress labour opposition. On the other hand, the absence of such a conflict creates opportunities for the systematic implementation of an agenda that disciplines workers without immediate punishment. ${ }^{2}$

To show how this process unfolds on the ground, this article compares politics of worker training in two cities that accommodate the same MNC: Bursa in Turkey, and Córdoba in Argentina. During the 1990s the relations between the management and the union were characterized by frequent conflicts in Córdoba. There, disciplining contentious workers rested heavily on swift punishment. On the other hand, the management in Bursa contained and eventually eliminated labour opposition without a systematic resort to the use of force: the 
number of industrial conflicts gradually decreased and a new disciplinary regime prevailed. The answer to understanding this puzzle lies in broader political dynamics that surround these actors.

The series of events that led to these outcomes began to unfold during the $1990 \mathrm{~s}$, when governments in Argentina and Turkey particularly encouraged automobile and auto-parts exports. ${ }^{3}$ These policies included providing special industrial protections in the form of subsidies, incentives and benefits during the initial stages of production. In both countries, automotive sector was named as the locomotive of development. The arrival of new investment by politically linked firms like FIAT also triggered the mushrooming of supplier belts with domestic and international producers nearby these factories. These policies also sought to lower unemployment by creating new and well-paying jobs. ${ }^{4}$ However, in order to create a competitive automobile industry, production processes in these settings needed a major restructuring.

FIAT stood out as a politically well-connected automobile firm with its long historical presence both in Turkey and Argentina. For example, in Argentina, FIAT managers had close links to members of the Peronist party-Partido Justicialista (PJ) - thanks to an early partnership agreement with the Macri group, known to be close to the PJ circles. When FIAT decided to expand its production, the company further benefited from government support and, after a major clash with UOM representatives, they welcomed a pro-PJ union (SMATA) to organize on premises. $^{5}$ Similarly, in Turkey, FIAT entered the Turkish market in partnership with Koc group, who enjoyed very close relationship with center-right political parties. ${ }^{6}$ The unionization process of the workers in this factory also followed a top-down route, and TURKMETAL was informally granted the sole authority to recruit rank and file members. ${ }^{7}$ Thus, in contrast to advanced industrialized countries, incoming FDIs heavily relied on political networks to exclude contentions unions through back-door politics and preapproved union elite was given the task of curbing potential labour unrest in both cases. ${ }^{8}$ 
Automobile producers like FIAT produce a variety of car models that are targeted to middle and lower-middle income groups. Unlike the luxury products where the manufacturers maximize profits through selling cars to wealthy customers with exorbitant price tags, companies that produce goods for the middle/lower-middle income group have to keep prices relatively affordable, and need to implement additional techniques on the shopfloor to facilitate surplus extraction and profit maximization. To ensure this, the workers need to exhibit uninterrupted commitment to achieve company goals, which calls for a newer approach than the one practiced under a Fordist production regime.

Fordist automobile production and subsequent technological advancements radically revolutionized the existing capital accumulation patterns after the textile mill. Very importantly, the launching of the assembly line in the 1900s increased greater control over the worker's manual labour on the moving band, allowing the employer to calculate the precise amount of extra-value to be taken-off from a worker's input. Because the automobile worker had no control over the speed of the moving band, s/he had to catch up with the production pace preset by the manager. This enabled controlled surplus value creation by pegging the employee to the band, and gradually turned the worker into a natural extension of the production machinery.

The emergence of new rivals on the scene such as Alfred Sloan's GM in the US, and the rise of new producers such as VW, FIAT, Renault and Citroen in Europe were initial challenges to the dominance of three Fordist principles, namely, product standardization, use of special purpose equipment, and the elimination of skilled labour in direct production. ${ }^{9}$ These producers essentially modified the implementation of Taylorist techniques on the shopfloor and pushed for technological improvements. However, these processes went through a radical restructuring after the 1980s. During this period, surplus extraction techniques inspired by those practiced at Toyota Corporation introduced new mechanisms of control over workers through quality trainings, proposal systems and 
teamwork. ${ }^{10}$ Very importantly, this upgrading called for a major disciplinary revolution in the workplace.

\section{Governmentality at the workplace}

We live in the age of discipline. Security cameras, X-ray machines and policemen are everyday acquaintances. Most prominently, the neoliberal disciplinary regime seeks to eliminate the use of immediate punishment not by rewarding obedience but through a process of repetitive indoctrination. According to Michel Foucault, disciplining individuals always requires some form of punishment. However, the methods of execution vary depending on how technologies of power operate on the ground. Thus, Foucault identifies three types. The first is the sovereign model, where punishment is a visible act with marks on the corpus, usually through ceremonial infliction of torture. This type of punishment was characteristic of the middle ages. With the advent of capitalism in the $19^{\text {th }}$ century, a new form of punishment emerged through the use of representative public signs in order to transform the subject to benefit the society (e.g. forced labour in prisons). Foucault refers to this as the social body model. Finally, with the advent of capitalism, a third model appeared where the coercive apparatus inflicted punishment through subjecting the individual to immediate coercion, often by training the body. ${ }^{11}$ With this type, "coercive, corporal, solitary, secret model of power" dominated the scene and the "physical exercise of punishment (which is not torture)" replaced the previously dominant forms of punishment. Foucault claims that this was possible because the power technologies in use enabled the control and regulation of docile bodies through hierarchized and functional surveillance, normalization of the judgment, the dual use of gratification and punishment techniques and systematic, ritualized examination of bodies. ${ }^{12}$

Even though Foucault's Discipline and Punish is primarily interested in documenting the dynamics behind the birth of the modern prison system, his third model - the coercive apparatus - offers useful hints to understand the transformation of body-politics in the 
workplace. The coercive and secret model of power also transformed the organization of the production. The new model now "took into account the activity of the men, their skill, the way they set about their tasks, their promptness, their zeal, their behavior". ${ }^{13}$ Surveillance on the shopfloor was a key mechanism for disciplining the workers. Additionally, these strategies were combined with rewards as a complementary mechanism to discipline workers. ${ }^{14}$

The contemporary launching of discipline without punishment in employee management went hand in hand with launching of neoliberal politics, whose origins dates back to 1970s. ${ }^{15}$ This first phase of neoliberalism was marked by the collapse of Bretton Woods system as advanced industrialized countries abandoned the gold standard, liberalized currency exchange and adopted capital account liberalization. In the following decade, financial liberalization policies — primarily led by the US and the UK — facilitated the increase of money supply in advanced industrialized economies. Worried about inflationary pressures, these governments then began to promote removal of national barriers to the global circulation of capital and supported overseas investment by their domestic firms to avoid inflation. ${ }^{16}$ The result of this political maneuvering gave way to the Washington Consensus with an open call by the IMF and the World Bank in favor of trade liberalization, privatization and financial liberalization in the Global South.

During this third phase - the 1990s — neoliberalism penetrated deeper beyond North Atlantic countries in the form of capital account liberalization. A common defining feature of this period is greater financialization in the advanced industrialized world and an increase in short-term capital flows and rising FDI into less developed areas. Thanks to these dynamics, most countries in the Global South suddenly found access to abundant and cheap capital, which, in turn, led to currency appreciation. ${ }^{17}$ This had a slow-down effect on exports in most of the developing areas. Thus, many export-oriented businesses — including FDIs — began to experience downfall in profits. In order to make up for their losses and avoid market-induced risks, firms began to focus on sustaining profits through greater surplus labour extraction. In 
doing so, production technologies inspired by Toyotism offered an attractive opportunity to these firms and transform employee behavior using novel strategies.

This process also coincides with the wide-scale diffusion of a new disciplinary regime beginning in advanced industrialized countries. ${ }^{18}$ The shopfloor techniques demanded an obedient workforce that is ready to make sacrifices for the well-being of the company. One of these early practices included quality circles. ${ }^{19}$ As early as 1970 s, these were seen as the best solution to enhance the efficiency of production. A quality circle is

“... a small group of between three and twelve people who do the same or similar work, voluntarily meeting together regularly for about an hour per week in paid time, usually under the leadership of their own supervisor, and trained to identify, analyze and solve problems in their work, presenting solutions to management and where possible, implementing the solutions themselves. "20

The frequent interactions between workers are expected to generate cooperation to eliminate problems in order to yield maximum efficiency in production. This requires workers' voluntary participation in brainstorming, data-collection, cause and effect analysis and the development of new control techniques. ${ }^{21}$ Additionally, surveillance, monitoring and the examination of worker participation are complementary techniques for profit maximization. But perhaps most importantly, quality improvement seeks to develop the principle of selfcontrol. $^{22}$ The goal is to enable the workers to pursue each task without the immediate monitoring of the supervisor. This practice saves energy and time, as long as workers are ready to commit themselves to voluntary participation. Punishing employees who are unwilling to cooperate does not help to generate perpetual dedication to perform better.

In order to generate this new worker profile, the management can use a variety of techniques. Those include developing a sense of awareness on the importance of quality and 
fostering worker self-identification with the corporate culture. ${ }^{23}$ On top of that, employees are encouraged to meet and socialize with one another during their leisure times. Picnics, competitions (e.g. soccer teams), other entertainments and philanthropic engagements (e.g. blood donations) are organized by the management to facilitate some bonding among the workers who perform similar tasks. Finally, some companies offer firm-based benefits to their employees. ${ }^{24}$ These methods serve an important goal: making the workplace an attractive location for the employees who are expected to perform better.

A common feature of these new disciplinary techniques is the gradual elimination of visible punishment. For example, if the worker decides not to participate in a quality circle, the management should not penalize him/her by paying a lower wage. In line with Burawoy's (1979) observations, peer pressure is expected to motivate the worker to take part in these meetings. This is a major shift from Fordist industrial relations that recognized conflict and negotiation as indispensable components of labour-management interaction. ${ }^{25}$ In the neoliberal era, discipline comes through intense and systematic behavioral training of the workers, in addition to surveillance and examination.

During the 1990s, quality circles were complemented by another highly influential method called Kaizen. Originating in Japan, Kaizen is an umbrella concept for a series of quality improvement techniques and primarily focuses on behavioral readjustment strategies. Overall, it emphasizes the merits of small improvements adding to greater performance. Whereas workers collectively identify and look for solutions in quality circles, Kaizen encourages each worker to make suggestions on how to improve performance and cut back costs.

In order to maximize obedience, Kaizen includes a number of steps. Among them, the $5 \mathrm{~S}$ technique is the most widely practiced set. This includes five principles. In the first step, the worker needs to differentiate between the necessary and the unnecessary tasks and discard the unnecessary ones. The next step requires putting things in order, which is followed by the 
third step that asks the worker to always keep his work station clean and orderly. The fourth step requires the worker to pay close attention to his personal hygiene and the final step asks him/her to follow instructions in the workshop. ${ }^{26}$ In addition to these principles, the system also asks the workers to keep the Five-Ws (Who, What, Where, When and Why) and the One $\mathrm{H}$ (How) in mind when performing their tasks. This is crucial for encouraging workers to make greater number of suggestions. High-performing workers are awarded certificates and praised with verbal kudos. Thus Kaizen allows the management to benefit from worker input at no extra cost: very commonly the symbolic rewards neither offer any material benefits nor immediate promotion.

However, the allegedly positive effect of these tactics are questionable because of the illusion of autonomy that Toyotism creates. While the group collectively works on problem solving, the employees have a limited power to implement solutions themselves. ${ }^{27}$ Furthermore, quality circles do not empower the workers because "they recommend improvements regarding changes in work methods and procedures but do not concern themselves with issues of more strategic change." ${ }^{28}$ But perhaps more importantly, higher profits are not reflected in the workers' wages: no one gets paid a higher sum when the suggestions made by a worker save the company thousands of dollars. ${ }^{29}$ In this way, the new disciplinary system excludes material rewards or higher-paying promotion as a source of voluntary worker motivation.

If there is no material gratification system to reward employees, how do corporations ensure the voluntary commitment of their workers? As our findings reveal, the consolidation of new discipline technologies requires additional resources beyond the workplace. Companybased training, workshops and social opportunities are not sufficient to create an obedient, flexible and dedicated workforce: new disciplinary technologies need to be embedded through an effective transmission belt. In particular, whether the state provides institutional channels for embedding this technology in broader societal networks plays a crucial role in the creation 
of a Toyotist worker profile. Very importantly, this process is largely influenced by the broader political context in which these actors interact.

\section{The Institutional Channels of Embedding New Disciplinary Technologies}

The link between the state, market and discipline was at the center of debates among the Marxist scholars during the 1960s and 70s. Most prominently, Althusser argued that with the advent of capitalism, state ideological apparatuses were designed and implemented precisely for controlling the hearts and minds of political subjects. ${ }^{30}$ According to Althusser, schools teach young children about the necessity of abiding by the behavioral codes of a capitalist social order. The socialization at school conditions the young minds to use reason and rationality in socially and politically acceptable ways. Similar to Foucault's coercive apparatus model, Althusser's argument emphasizes that obedience to authority is necessary but not sufficient: through education, individuals are disciplined in a way that guarantees future commitment to reproducing the system in which they live.

We build on these debates by adding an important caveat: not all state institutions discipline their citizens the same way because national political economies are not identical copies of one another. ${ }^{31}$ There are notable variations in how capitalist institutions are organized. These differences are even starker in industrializing settings. At the very least, the degree of state involvement in coordinating market exchanges varies. ${ }^{32}$

Education is one such transmission belt through which market expectations are implanted in young minds from a very early age onwards. Given divergent development trajectories of capitalist market building across the globe, education and training programs also differ across and within national political systems. ${ }^{33}$ For example, while Germany allocated higher share of resources to public vocational schools, ${ }^{34}$ the US and the UK encouraged private training. Moreover, most countries in the Global South did not follow identical routes taken by advanced industrialized countries. Therefore, variations in 
disciplinary tools for governing the labour are best understood by identifying political conditions under which these transformations occur.

At the local level—and especially in industrial districts — an important prerequisite for mobilizing resources to transform the vocational education system requires a strong political alliance between the state officials and the business groups. This is necessary to develop a roadmap to retrain workers, share costs and build long-term disciplinary strategies. In designing this apparatus, state officials and business representatives have to share information frequently. However, when these parties find themselves in opposing camps, cooperation over devising new technologies to ensure worker discipline is less likely.

The figure below summarizes two pathways of disciplinary outcomes driven by the relationship between business groups and state officials. When these parties are involved in a conflict, they have different priorities and are unwilling to collaborate on implementing disciplinary technologies in a concerted fashion. Under these circumstances, there is no early exposure through vocational education. Thus, labour is more likely to mobilize whenever they feel their well-being is under threat. In response, business resorts to discipline by punishment and is more likely to rely on forceful measures to repress unruly workers. As the next section elaborates, experiences of FIAT workers in Turkey in 1994 and their counterparts in Argentina during the 1990s follows this path. 


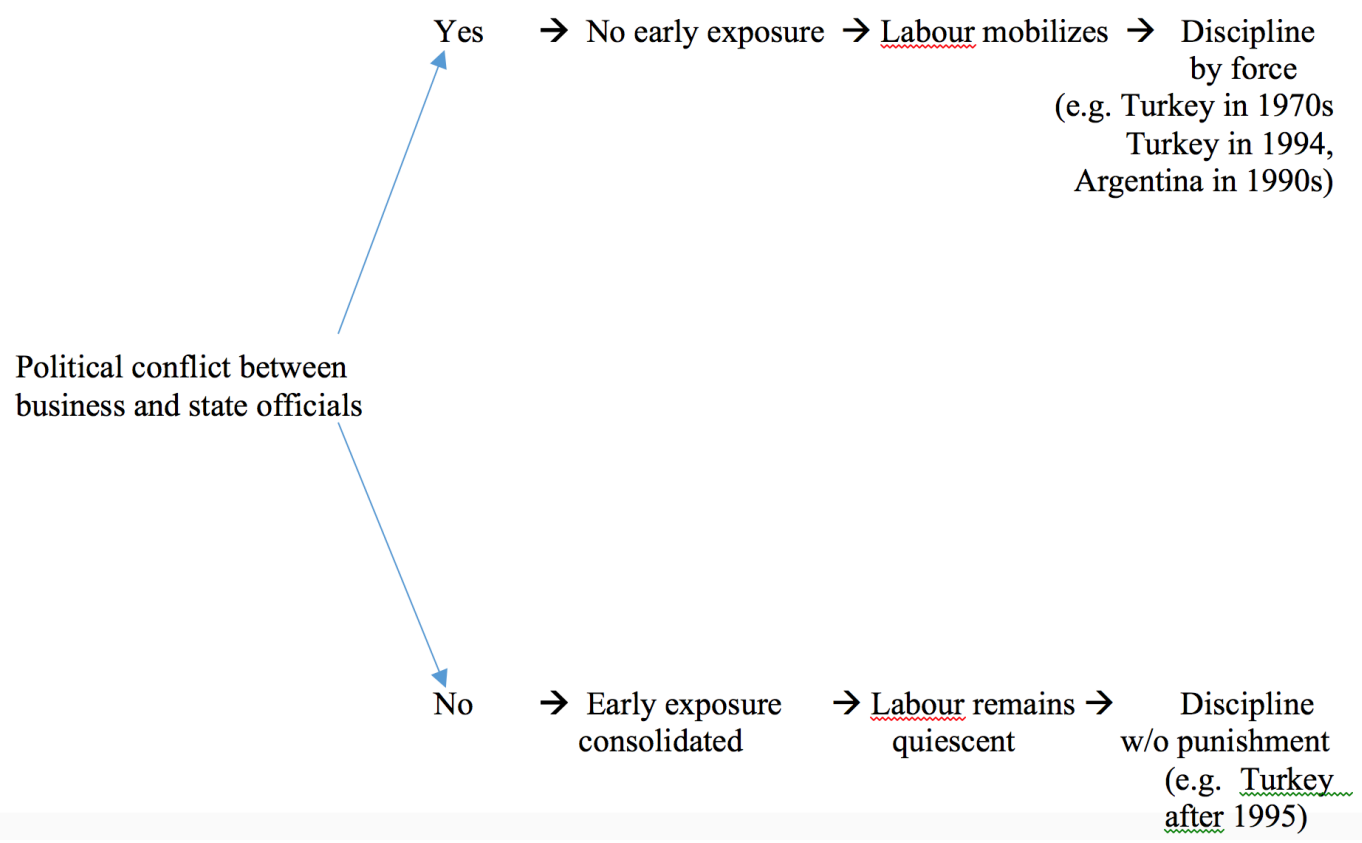

Figure 1. Overview of disciplinary pathways

Where no such conflict exists between business groups and state officials, collaboration to incorporate new disciplinary technologies is much more likely. As we will see, this alliance facilitates the incorporation of Toyotism-inspired modules into the vocational education curricula, enabling early exposure to business expectations from a very young age. Later, when these students join the workforce as employees, they are readier to follow their supervisors and act according to the management protocol in resolving any shopfloor disagreement or workplace conflict. Rather than initiating collective mobilization or seeking union support, these workers increasingly endorse conflict resolution techniques and negotiate with their managers on an individual basis. Effectively, unions remain quiescent, and discipline without punishment gradually takes root in the long run.

To unpack these processes, the next section focuses on the processes of incorporating industrial disciplinary technologies in Bursa and Córdoba, which are two cities that host the factories of the same MNC. In Bursa, the absence of a major political conflict between state officials and business helped the consolidation of discipline without punishment among the blue-collar workers through an institutional platform: the vocational education council. On 
the other hand, political conflicts in Córdoba involving federal government, local politicians and business prevented the consolidation of a similar disciplinary regime, and punitive practices prevailed as the dominant policy.

\section{Consolidating New Disciplinary Technologies in Bursa}

During the 1970s, the workers employed in Bursa factory produced cars following the principles of the Fordist assembly line. The management hired workers with no or little industrial background; trainings were usually given on the job. A corporate culture existed at the top level, but there was no factory-wide, top-to-bottom diffusion of these principles. ${ }^{35}$ The relations between the management and the union leaders were characterized by frequent conflicts, which usually resulted in walk-offs, work stoppages, protests and strikes. ${ }^{36}$ These confrontational exchanges were embedded in broader political conflict patterns. The 1970s were characterized by fierce conflicts between state and social actors in Bursa and left wing political groups often clashed with supporters of right wing nationalists. As such, production in Bursa, including at this factory, was frequently disrupted. ${ }^{37}$ Discipline was maintained through immediate punishment incompliant workers by visible penalizations, including dismissals and police arrests.

The 1980 coup further changed the picture and the military government began to prepare the ground for market liberalization. ${ }^{38}$ Budget deficits and balance of account problems had worsened under the Import Substitution Industrialization (ISI) system during the $1970 \mathrm{~s} .{ }^{39}$ Consequently, the political coalition between the business and the military officers pushed towards an export-oriented regime. This called for a major suppression of wages and elimination of labour conflict. ${ }^{40}$ Achieving both objectives required a welldisciplined labour force.

The transition from an ISI-based system to export-oriented production in Bursa unfolded in a number of steps. During the initial stages, the automobile producers continued to work with Fordist principles but the managers began to make ad-hoc modifications in the 
production line. In the Bursa factory, this included training team leaders who could communicate principles of quality improvement to other workers. ${ }^{41}$ These team leaders had a double function. Just like a panopticon, they served as the management's eye on the shop floor to identify problem-workers. At the same time, these team leaders were responsible for instructing workers on acceptable modes of behavior in the workplace.

During the initial stages of export-oriented production, the government in Ankara prioritized suppressing wages. ${ }^{42}$ Therefore, during the 1980 s, the Ozal government imposed severe restrictions on labour rights and allowed imprisonment of those who opposed those changes. ${ }^{43}$ The business community generally supported these measures and large companies aligned themselves with the Ozal government. Nevertheless, during this transition stage, immediate punishments coexisted with subtler ones. For example, contracts of employees with a left-wing political orientation could be more easily revoked. Overall, the priority was on the elimination of uncooperative or potentially unfit workers. ${ }^{44}$ In line with this policy, the management of FIAT in Bursa welcomed a very conservative union that shared this outlook on the factory premises.

However, even though the company had the support of the government and the "yellow" union, creating a self-disciplined labour was not an easy task. The punitive measures against militant workers imposed by the central government did not automatically translate into creating an obedient workforce. Buying-off union leaders without an effective strategy to win the hearts and minds of rank-and-file did not completely eliminate risks associated with labour unrest. This required detailed knowledge of the political orientations of the workers. Therefore, the management in the Bursa factory solicited the help of local officials, including the governor, security forces and local office of the ministry of labour. This arrangement made background checks of the candidates easier and the management began to recruit new workers who did not have any experience with political activism or engagement. ${ }^{45}$ 
In 1991, the workers were introduced to the concept of quality circle for the first time. Initially, the reaction of the workers to quality circles was mixed. While those who had a vocational background were curious, others who were recruited through personal references did not seem very enthusiastic. For example, worker YNK was skeptical about the effect of these trainings: "even though the [new] workers ha[d] former training, they $d[i d]$ not have the experience that I have". ${ }^{46}$ The graduates of vocational schools also did not feel very comfortable with the new technique at first. For example, worker RSD recalls quality circles as moments when "he felt under the spotlight". That's why he "was quite shy to participate in the meetings" ${ }^{47}$ The introduction of quality circles caused some doubt among the more experienced workers who did not have formal training experience. Some workers felt they no longer had any control over their job.

During the early 1990s, the management continued to recruit workers without any formal training and paired them with more experienced workers. The memories of a politicized labour force from the late 1970s were still alive and the factory managers wanted a completely new group of workers only to be trained by the company. But when the next economic crisis hit in 1994, the workers-including the newly recruited ones-launched fierce protests against the mass lay-offs. During this period, the workers took advantage of an ongoing tension between the government and big business groups to voice their demands in even louder tones, where the latter severely criticized the former on its crisis management policies. ${ }^{48}$ Meanwhile, the management punished those who participated in the protests by revoking their contracts. At the same time, the management decided to break-off existing teams and assigned workers to different work-stations. This was partially because of the unforeseen side-effects of quality circles: workers who took part in protests were often part of the same circle that met regularly. Therefore, the management wanted to eliminate the building of strong ties by rotating workers across different units with increasing frequency. 
On December 31st 1995 the Customs Union agreement with the EU; a treaty enabling free trade between the EU and Turkey; was put into effect. ${ }^{49}$ Economic liberalization pressures were becoming more visible. The automobile industry was still protected by some measures but the opening of the domestic market to European cars marked the beginning of a more competitive environment for the Bursa factory. ${ }^{50}$ This required uninterrupted, high-quality production. In a next step, the management introduced Kaizen techniques on the shopfloor. Additionally, the company decided to give preferential treatment to candidates with formal vocational degrees. ${ }^{51}$ To facilitate this process, the human resources department approached the vocational high school principals in Bursa and informed these schools about the candidate qualifications they were interested in. ${ }^{52}$

At the same time, the management also began to lobby for curricula updates in the Bursa Vocational Education and Training Council. ${ }^{53}$ This was an institutional platform responsible for coordinating skill formation policies in public schools and training centers with the participation of local producers, bureaucrats and the union representatives. It was established by the Ozal government in 1986 and stayed active until 2008. In Bursa, this forum played a key role in transforming the hearts and minds of future workers in a unitary setting beginning in the second half of the 1990s.

While the 1994 economic crisis triggered a major tension between big business groups and the government, the second half of the 1990 s was characterized by a gradual reconciliation especially following Tansu Ciller's departure from the political scene. During this period, the political consensus among the government and business facilitated the embedding of new behavioral expectations in the vocational education curricula as demanded by industry leaders. In the absence of a major political conflict surrounding this process, council members were relatively quick in reaching an agreement on incorporating behavioral techniques and reengineering vocational education and training system into a transmission belt for early student exposure to Toyotist production schemes. ${ }^{54}$ 
Once the council members agreed on the required program changes, the school principles and teachers undertook the effort to implement the decisions. In Bursa, vocational school principals, teachers and officials are appointed by a centralized administration controlled by the Ministry of Education. These career bureaucrats rarely step out of the policies outlined in Ankara because their benefit packages and promotion paths depend heavily on how closely they follow the guidelines issued at the center.

\section{Creating “Quality” Minds: Embedding New Disciplinary Technologies in Bursa}

Between 1990 and 1998 the principal of Demirtaspasa Industrial Vocational High School who attended the meetings in Vocational Education and Training Council. Following his retirement, a new principal took over his position. In addition to intern placements, the new principal set up a training program for student participation in teamwork and collaborated with other technical school managers for writing a handbook of total quality management to complement the curricula at schools in Bursa. ${ }^{55}$ This textbook specifically highlights customer demands as the driving force of the new economy and underlines the indispensability of competition for constant improvement in quality, suggesting that this could be primarily achieved through a collaborative teamwork among workers. In addition, the Tophane Industrial and Technical High School principal played an equally important role in mobilizing the network of schools and businessmen. The principal of this school served for thirty years between 1971 and 2001 and under his management, Tophane signed a cooperation and brotherhood agreement with Hans Wildorf Schule in Germany as early as 1985. As a result of this collaboration, Tophane students began to be exposed to quality trainings as early as the late $1980 \mathrm{~s} .{ }^{56}$

The early introduction of these behavioral modules in vocational high schools across Bursa began to make a difference. In the words of the Industrial Operations manager: 
"there is a clear difference between those who come from the vocational high schools in Bursa and older workers without a similar training. [The former] have a solid background and it is much easier to train them, because they get what we give them ... overall, better quality benefits everyone". 57

The profile of the workers at the Bursa factory went through a gradual transformation since 1995. The number of worker proposals significantly rose. ${ }^{58}$ Meanwhile, workplace-related conflicts were on the decline. Rather than taking up the route of collective action, conflict resolution and negotiation trainings began to be preferred techniques to address crises on the spot. ${ }^{59}$ In that sense, the gradual decline of rank and file trust in the union is quite telling. With the exception of shop floor leaders, nearly all of the Bursa factory workers I interviewed expressed their discontent with the union. ${ }^{60}$ There is a growing indifference towards the union management, strongly mixed with resentment. In the words of these workers:

“...the union management just takes my money, and does not do anything else”. ${ }^{61}$

“...the union leadership...does not come and talk to us, they don't ask our opinion on anything", 62

In sum, beginning from their early days as students at vocational schools, workers in this factory were systematically trained to follow behavioral principles inspired by Toyotism. This alliance continued well into the 2000s where FIAT managers collaborated closely with vocational schools in Bursa. Perhaps the photo below best summarizes this partnership: below, we see students posing in front of FIAT lab of Hurriyet Vocational High School in Bursa where the company regularly recruits graduates as new employees. ${ }^{63}$ 


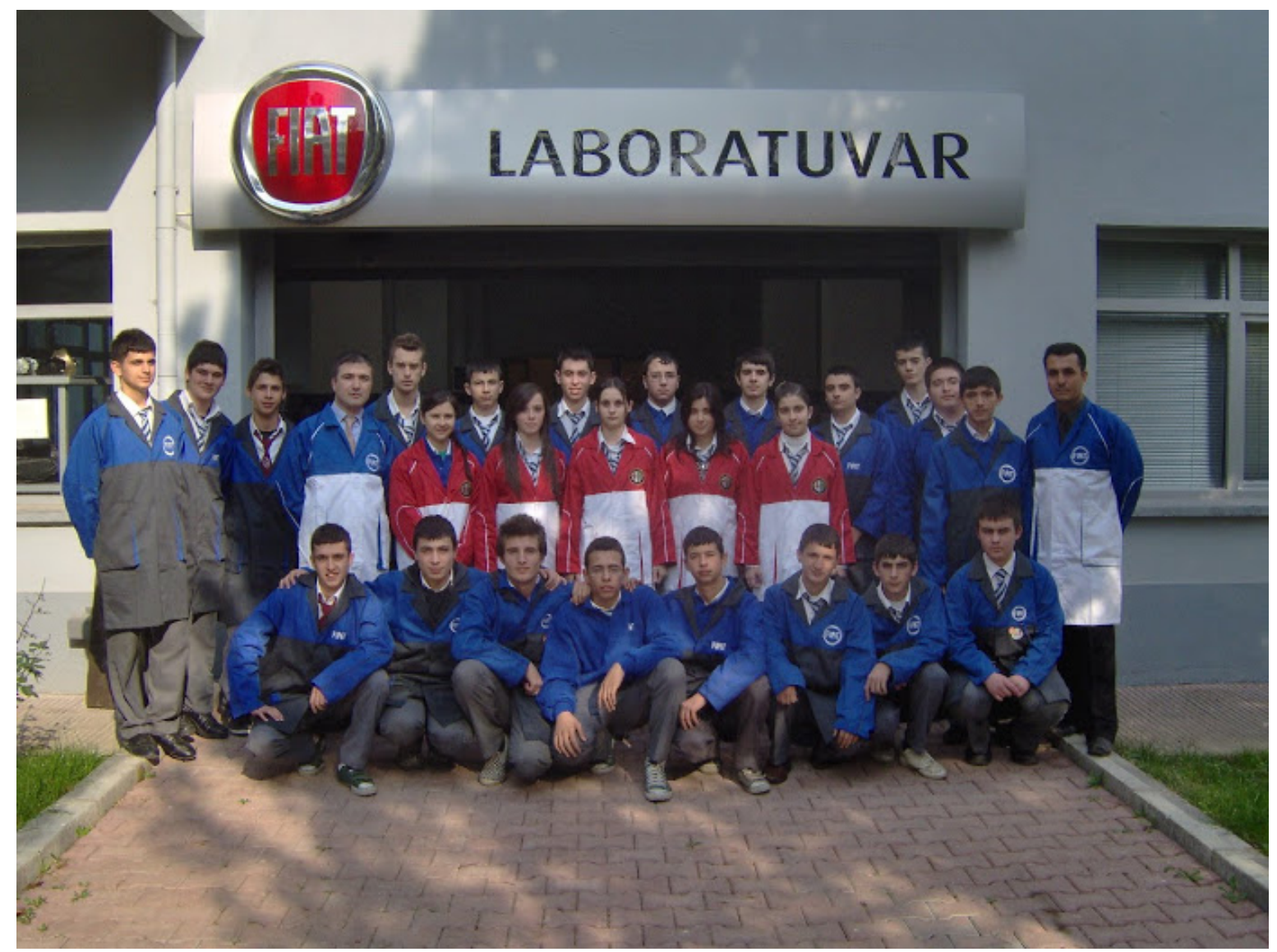

Illustration 1. Hurriyet Vocational High School Students in front of FIAT Training Lab in Bursa, photo circa 2008, Taken from: http://hurriyetemlfiat.blogspot.com/

Thus, by embedding these programs in public vocational school curricula, the state and local officials in Bursa played a key role in embedding these disciplinary technologies in the minds of future employees. However, these strategies simultaneously eliminated the development of solidarity ties among the workers, and unions gradually turned into strongly disliked empty shells.

To further reveal the significance of politics and state institutions in the consolidation of disciplinary techniques, the next section unpacks the contrasting experiences of the workers of the same company located in a different city: Córdoba, Argentina. The workers of the Córdoba factory were exposed to the same behavioral training techniques by the firm, but their protests and strikes continued whenever work-related problems arose. What marks the difference between the two is the political context that surrounds these actors. Specifically, an 
ongoing and extended political conflict between the federal and local state authorities undermined the consolidation of discipline without punishment in Córdoba. During this process, FIAT's close ties to the federal government turned into a major liability. The next section unpacks this story.

\section{Córdoba: a difficult encounter}

The history of automobile production in Córdoba is very similar to the trajectory in Bursa. During the 1990s, factory managers in both settings implemented the same training techniques at the shop floor. The workers in Córdoba were also exposed to quality circles and Kaizen. ${ }^{64}$ But by the end of 1990s, these new behavioral training techniques were still contested by the workers on the shopfloor, and labour conflicts escalated quickly. Sometimes, the intensity of these protests was such that workers occupied the factory and adopted militant tactics against unfavorable decisions of the management. These protests were usually repressed, and the management punished participating workers by revoking their contracts. If the company management deployed the same set of training tools, what explains the non-compliance of Córdoba workers during the 1990s?

The clue to this puzzle lies in political disagreement between the local and central government in a federal setting. In Córdoba, local and federal politicians were politically divided over the implementation of neoliberal reforms pushed by the Carlos Menem government. Collaboration on disciplining workers was not on the agenda because the local government lacked funds to finance a radical revamping of vocational schools. Thus, the strife between business and labour on the implementation of new production schemes was masked by broader conflicts between the local and federal government on the use of public funds.

Just like their counterparts in Bursa, the Córdoba workers carried production along Fordist principles before the 1990s. Automobile production was largely for the domestic consumption. The company recruited workers with little or no training, often from the nearby 
towns and villages. ${ }^{65}$ The new recruits learned the job alongside more experienced workers. Discipline in the workplace was maintained through direct punishment of the unruly employees. ${ }^{66}$ Labour-management relations were characterized by frequent conflicts. During the first half of 1970 s, the workers continued with protests, walk-offs and strikes. ${ }^{67}$ In response, they faced punishments mostly in the form of lay-offs and police arrests.

Moreover, labour-management relations further changed after the 1976 coup. The military government used brutal tools — including torture and mass killings — for punishing thousands of workers and left-wing supporters during the infamous dirty war between 1976 and $1983 .{ }^{68}$ Just like the military government in Turkey, the junta leaders were in favor of launching a more liberal economic regime. ${ }^{69}$ Peronist economic policies that supported production for the domestic market were renounced. Instead of ISI, the junta promoted exportoriented production. ${ }^{70}$ In order to do that, opposition had to be eliminated; and the labour force had to be disciplined.

Yet, the junta faced growing domestic and international pressures over their human rights abuses and confronted major economic and financial crises. By 1983, following the Malvinas/Falklands war, the military government turned power into the hands of the civilians. Following the transition to democracy, the newly elected Union Civica Radical (UCR) government continued with export-led growth policy and offered benefits initially to the agrobusiness groups. ${ }^{71}$ During the Raul Alfonsin government, the policies for restructuring the manufacturing industry took a back seat. ${ }^{72}$

The local governor of Córdoba — Eduardo Angeloz — was also from the UCR and his political supporters included domestic agro producers rather than big industrial manufacturers. While Angeloz and his domestic supporters benefited from the policies promoted by Alfonsin, the manufacturers and international capital groups in Córdoba had minimal contact with the local government. However, the presidential elections in 1990 changed the picture. When Peronist Party (Partido Justicialista-PJ) came to power, existing political alliance between 
the federal government in Buenos Aires and the UCR controlled government in Córdoba was no longer in place. Just like Turgut Ozal and his successors in Turkey, Menem launched an ambitious liberalization of the Argentine economy. During the early years in government, Menem also gave preferential treatment to automobile producers and installed special protections. ${ }^{73}$ At the same time, Menem's emphasis on this sector as the new locomotive of development called for a change in skill formation policies to consolidate discipline among workers to avoid unwanted disruptions. ${ }^{74}$

However, the intensification of political conflict between Córdoba and Buenos Aires created additional difficulties to pursue this agenda. Governor Angeloz opposed Menem's policies that prioritized the automobile industry. ${ }^{75}$ According to Angeloz, developing human capital requires investment in general education, and not just in vocational education. ${ }^{76}$ Disciplining workers into obedient employees did not serve the developmental goals of any country, let alone Córdoba. ${ }^{77}$ As the central government simultaneously pushed for the decentralization of education and asked local governments to cover for the costs, Angeloz invested a larger share of local funds to increase enrollment in primary education. ${ }^{78}$

The political conflict between Menem and Angeloz began when both were candidates for the presidential elections in 1988. After Angeloz lost the election, their rivalry was further intensified. While Menem had a close relationship with big domestic industrialists and international producers, Angeloz's relations with business was limited to local business groups, operating in the agricultural and construction sectors. Furthermore, Menem had the full support of the largest union organized in the automobile production. ${ }^{79}$ Unlike their counterparts in Turkey, Menem and Angeloz did not share a common agenda neither on how to discipline the workforce, nor on the priorities of economic development.

Aware of the political rivalries, the company management tried to sidestep local state agencies and directly approached the federal government in Buenos Aires to launch a collaborative training program in $1995 .{ }^{80}$ According to an agreement between the two parties, 
the federal government would cover the training costs of newly recruited workers. The company instructors who specialized in the new production techniques would train the old and newly recruited workers on the factory premises. These new modules included some technical training but the greater part of the program was focused on behavioral modification. Meanwhile, in early 1995, Angeloz resigned from his post due to allegations of corruption. ${ }^{81}$ His successor Ramon Mestre was also from the UCR. Upon his arrival to office, Mestre found Córdoba in high debt. To avoid insolvency, he desperately needed funds. Angeloz's failure to attract credit from the federal government and Menem's blocking of Angeloz's attempts to seek external credit in the US put Córdoba in a nearly bankrupt condition. ${ }^{82}$ Mestre could no longer afford this: in order to attract funds from the central government, he carefully avoided getting involved in a political conflict with Menem, ${ }^{83}$ and announced his support to the automobile industry in Córdoba. ${ }^{84}$ As a result, some federal funds were released by the central government for Mestre's use. ${ }^{85}$ However, the amount transferred was just enough to save a teetering provincial economy and Mestre lacked resources to invest in schools.

Hoping to exert more control over the workers for surplus extraction, and with additional support from the Mestre government, the factory managers bargained hard with the union leaders to keep yearly salary increase rates at a lower rate. However, once the workers found out about the new terms of collective agreement, this triggered strong sentiments of discontent among the workers. The shopfloor leaders, who were initially interested to find out more about the new training programs, began to accuse the factory management of "brainwashing". Soon, the old workers launched a violent protest at the factory, occupying the production facilities for days. ${ }^{86}$

The older workers of the factory opposed the new measures and flexible production techniques introduced in collaboration with the federal government. ${ }^{87}$ The leader of the protests resisted the launching of new training modules, arguing that "these [were] the new 
tactics of repressing labour opposition...these training modules [did] not benefit the workers at all... They [were] preparing us mentally to accept the principles of flexible production" ${ }^{88}$ Just like during the early 1990s in Bursa factory, without the support of the local government, the company's sole efforts to discipline the workers with new behavioral training modules proved to be ineffective. To keep protests under control, Mestre deployed the police against the protesters. ${ }^{89}$ Some workers who got involved in the protests were immediately laid off. ${ }^{90}$ Discipline came with punishment.

Following these events, the management launched a new policy, hiring a completely new set of workers with minimum or no training, mostly from nearby surrounding rural areas, without any political commitments ${ }^{91}$. Subsequently, the number of workers with a formal training background significantly reduced. Unlike their counterparts in Bursa, the management was hesitant to hire workers with a formal training on the grounds that workers with higher education were more likely to be politicized. ${ }^{92}$ Given the political turmoil in the Province and financial difficulties experienced by the local government, Córdoba managers showed no interest in local vocational schools as a potential recruitment pool and were reluctant to unilaterally finance any restructuring of the curricula along principles inspired by Toyotism.

Thus, it was the management alone that immersed newly hired workers in a behavioral training program. But the workers also had mixed perspectives on the usefulness of new techniques. Some had doubts about the effectiveness of quality circles and others were unwilling to participate in the system of worker suggestions. Older workers who survived the wave of mass lay-off in 1996 and 1997 exhibited doubts about the effectiveness of these tools. ${ }^{93}$ Thus, the sole efforts of the factory management in the midst of political conflicts in Córdoba did not suffice to generate worker dedication to company goals.

Unlike in Bursa, the Córdoba factory continued to be the site of protests during the latter half of the 1990s and the local union leadership played a key role in this process. Indeed, 
these workers were not apathetic towards the union: though there were some complaints about the effectiveness of local leadership, the union was the main medium of negotiations at times of industrial conflict. For example, when a shopfloor leader of the 1996 protests was laid off, the workers collectively mobilized through the union. ${ }^{94}$ When fifty-four workers were laid off due to economic crisis in December 1997, the workers first approached the union for resolving the problem. ${ }^{95}$ Finally, when the relations between the management and the union got tense during the 1998 economic crisis, the workers mobilized through the union to stop the layoffs. ${ }^{96}$ Unlike their counterparts in Bursa, Córdoba workers did not develop a sense of indifference vis-à-vis local union leadership when faced with similar conflicts. This is because a federal setting allowed local union branches to develop some autonomy to act independently of the guidelines pushed by headquarters in Argentina, and exploit broader political conflicts between the two governments in order to keep rank and file on board as due paying members.

\section{Conclusion}

Disciplining the labour force is not a new phenomenon. But disciplining the labour force with or without immediate punishment is a new distinction. This is pivotal to understand contemporary industrial relations in developing settings. Discipline with punishment is characterized by a swift penalization of the worker for being uncooperative in following managerial demands and expectations. On the other hand, new disciplinary techniques that were introduced during the neoliberal era embody technologies where the worker is not immediately penalized, but exposed to repetitive and systematic behavioral training to internalize business expectations through multiple channels, first beginning at school. Conceptualizing discipline as a process, this article argues that the consolidation of new disciplinary technologies in developing areas is contingent on the political context in which these stakeholders operate.

The comparative analysis of worker experiences in two factories of the same multinational company further reveals that this process is heavily influenced by the broader 
political dynamics that surround these actors. As the case of Córdoba shows, the mere exposure of employees to factory-based behavioral modules does not automatically transform the labour into docile bodies. Rather, it is the intensity of political conflict involving local and central officials and company representatives that determines whether discipline comes with or without punishment. While a political disagreement over economic liberalization led to the immediate punishment of workers in Córdoba, political consensus among stakeholders in Bursa facilitated the broader embedding of new disciplinary technologies.

The comparison of distinct worker experiences in Bursa and Córdoba also reveals an important tension in developing countries. While discipline without punishment may contribute to higher levels of productivity, it minimizes organized worker opposition against the failures of the capitalist development (e.g. growing quiescence vis-à-vis economic crises). Most notably, these techniques instigate apathy vis-à-vis the union and lack of worker commitment to collective action presents a major threat to democratization. This is most clearly manifested in the Turkish case, where a sharp decline in the unionization rate over the past two decades and a half went hand in hand with elimination of organized labour as an important political force, creating room for the rise of conservative-populist parties with dubious democratization records. ${ }^{97}$

Much of the earlier studies on democratization reveal that labour movements played a pivotal role in transition from an authoritarian to democratic regimes by constantly challenging their governments via demonstrations, protests and strikes. ${ }^{98}$ This is most prominently the case in late-democratizing countries, including Spain, Peru, Brazil and Argentina. In the case of the latter, democratic consolidation - although not free of conflictwas further bolstered by the emergence of progressive and independent labour unions in the societal arena-most recently in the 1990s. Thus, while discipline with punishment may not have productivity enhancing effects in Argentina, it gave more leverage to organized worker opposition and unions continued to act as powerful actors in the political arena. These 
dynamics are conspicuously absent in the Turkish case, and the accelerating authoritarian drift under Tayyip Erdogan's leadership is further emboldened by the alarmingly low union density rates. This poses a major threat to Turkish democratization as discipline without punishment dominates industrial relations, unions lose power and workers increasingly become vulnerable to defend their most basic rights.

On a final note, these findings also point to the crucial role of the state in the age of discipline, especially in developing areas. The Bursa-Córdoba comparison reveals that the techniques invented by capital are necessary but not sufficient to generate a disciplinary transformation at the workplace. These tactics are influential so long as they are internalized by workers who see no alternative. This is the underlying assumption of Foucault's later works on biopolitics and governmentality. ${ }^{99}$ In that sense, the hegemonic consolidation of new technologies depends on the degree to which they are embedded in broader societal networks. In the neoliberal era, however, this is a political process where the state still plays a pivotal role in surplus extraction and capital accumulation in developing settings.

\section{References}

Althusser, Louis. 'Ideology and Ideological State Apparatuses (Notes toward an Investigation)', pp. 86-111 in A. Sharma and A. Gupta (ed), The Anthropology of the State. Oxford: Blackwell Publishing. 2006.

Apaydin, Fulya. "Partisan Preferences and Skill Formation Policies: New Evidence from Turkey and Argentina." World Development. Vol. 40, no. 8 (2012): 1522-1533. Doi: 10.1016/j.worlddev.2012.04.006

Barbero, Maria. I. \& Motta, Jorge. "Trayectoria de la Industria Automotriz en Argentina Desde Sus Inicios Hasta Fines de la Decada de 1990." In Marcelo. Delfini, Daniela Dubbini, Manuel Lugones and Ivana. N. Rivero (eds), Innovación y empleo en tramas productivas de Argentina. Buenos Aires: Prometeo Libros. 2007.

Barry, Andrew; Thomas Osborne and Nikolas Rose (eds.). Foucault and Political Reason: Liberalism, Neo-Liberalism, and Rationalities of Government. London: The University of Chicago Press. 1996.

Blind, Peride. Democratic Institutions of Undemocratic Individuals. New York: Palgrave. 2009. 
Boratav, Korkut. "Inter-Class and Intra-Class Relations of Distribution under "Structural Adjustment": Turkey During the 1980s." In Tosun Aricanli and Dani Rodrik (eds), The Political Economy of Turkey: Debt, Adjustment and Sustainability. New York: MacMillan. 1990.

Boratav, Korkut., Oktar Turel and Erinc Yeldan. "Dilemmas of structural adjustment and environmental policies under instability: Post-1980 Turkey" World Development, Vol. 24, no.2 (1996), 373-393. http://dx.doi.org/10.1016/0305-750X(95)00140-8.

Bosch, Gerhard., Jean Charest. "Vocational training and the labour market in liberal and coordinated economies" Industrial Relations Journal, Vol. 39, no.5, (2008), 428-447. Doi: 10.1111/j.1468-2338.2008.00497.x

Burawoy, Michael. Manufacturing Consent: changes in the labour process under monopoly capitalism. Chicago: University of Chicago Press. 1979.

Burchell, Graham, Colin Gordon and Peter Miller, P. (ed.) The Foucault Effect: Studies in Governmentality. Chicago: University of Chicago Press. 1991.

Chaudhry, Kiren Aziz. "The Myths of the Market and the Common History of Late Developers", Politics and Society, Vol. 21, No.3 (1993), 245-274. Doi:

$10.1177 / 0032329293021003002$

Collier, Ruth Berins and James Mahoney. "Adding Collective Actors to Collective Outcomes: Labour and Recent Democratization in South America and Southern Europe." Comparative Politics, Vol.29, no.3 (1997), 285-303.

Crosby, Philip. Quality is Free: the Art of Making Quality Certain. New York: Mentor Books. 1979.

Culpepper, Pepper. "Small States and Skill Specificity: Austria, Switzerland, and Interemployer Cleavages in Coordinated Capitalism" Comparative Political Studies, Vol.40, no.6, (2007), 611-637. Doi: 10.1177/0010414006295927

Deneault, Alain. Offshore: Tax Havens and the Rule of Global Crime. New Press. 2011.

Duruiz, Lale, "Globalization Efforts of Turkish Car Industry”, Seventh International Colloqium, GERPISA, Paris,June 1999.

Edwards, Richard. "Mobilizing lifelong learning: governmentality in educational practices", Journal of Education Policy, vol. 17, no.3, (2002), 353-365.

http://dx.doi.org/10.1080/02680930210127603

Falleti, Tulia. "Descentralizacion educativa en Argentina: Condicionantes Institucionales y Consecuencias Politicas." In Clemente, A. y Smulovitz, C. (eds.) Descentralización, políticas sociales y participación democrática en Argentina, Buenos Aires, Instituto Internacional de Medio Ambiente y Desarrollo y Woodrow Wilson Internacional Center for Scholars, p. 93-122. (2004). 
Ferreyra, Horacio A. Transformacion de la Educacion Media en la Argentina. Córdoba: Editorial Universidad Catolica de Córdoba. 2006.

Finlay, Ian, Stuart Niven and Stephanie Young, S.. (eds.). Changing Vocational Education and Training. London: Routledge. 1998.

Foucault, Michel. Discipline and Punish: The Birth of the Prison. London: Penguin Books. 1991.

Foucault, Michel. The Birth of Biopolitics: Lectures at the College de France, 1978-1979. New York: Palgrave MacMillan. 2008.

Fraser, Nancy. "From Discipline to Flexibilization? Rereading Foucault in the Shadow of Globalization" Constellations, Vol. 10, No.2 (2003), 160-171. Doi: 10.1111/14678675.00321 .

Gerschenkron, Alexander. Economic Backwardness in Historical Perspective. Cambridge: Belknap Press. 1962.

Grote, Dick. Discipline Without Punishment. New York: Amacom. 1995.

Haggard, Stephen and Robert Kaufman. "The Political Economy of Democratic Transitions", Comparative Politics, Vol.29, No.3 (1997), 263-283. doi:10.2307/422121

Hall, Peter and David Soskice (eds.). Varieties of Capitalism: The Institutional Foundations of Comparative Advantage. New York: Oxford University Press. 2001.

Hayek, Friedrich. The Road to Serfdom. London: Routledge. 1944.

Hayek, Friedrich. Law, Legislation and Liberty: Rules and Order. Chicago: University of Chicago Press. 1978.

Hutchins, David. Quality Circles Handbook. London: Pitman Publishing. 1985.

Imai, Masaaki. Kaizen: The key to Japan's competitive success. New York: McGraw-Hill Publishing. 1986.

Iversen, Torben and John D. Stephens. "Partisan Politics, the Welfare State, and Three Worlds of Human Capital Formation", Comparative Political Studies, Vol.41, no.4-5 (2008), 600-637. Doi: 10.1177/0010414007313117

Kelemen, Mihaela. Managing Quality. London: Sage Publications. 2003.

Kivinen, Osmo and Risto Rinne. "State, Governmentality and Education: the Nordic experience", British Journal of Sociology of Education, Vol. 19, No.1 (1998), 39-52. http://www.jstor.org/stable/1393178

Lanari, Maria. E. La política de empleo en los países del Mercosur (1990-2003). El caso de Argentina. Buenos Aires: OIT. 2003. 
Lemke, Thomas. "The Birth of bio-politics: Michel Foucault's lecture at the College de France on neo-liberal governmentality", Economy and Society, Vol. 30 no.2 (2001), 190207. Doi: $10.1080 \% 2 F 03085140120042271$

McCarthy, Cameron and Greg Dimitriadis. "Governmentality and the Sociology of Education: media, educational policy and the politics of resentment" British Journal of Sociology of Education, vol. 21, no.2 (2000), 169-185. http://dx.doi.org/10.1080/713655350

Mercenier, Jean. and Erinc Yeldan. "On Turkey's trade policy: Is a customs union with Europe enough?”, European Economic Review, vol.41, no.3-5 (1997), 871-880. https://doi.org/10.1016/S0014-2921(97)00044-5

Miozzo, Marcelo. "Transnational Corporations, Industrial Policy and the War of Incentives: the case of the Argentine Automobile Industry." Development and Change. Vol. 31. No.3 (2000): 651-680. doi:10.1111/1467-7660.00171

Munck, Gerardo. Authoritarianism and Democratization: Soldiers and Workers in Argentina, 1976-1983. University Park: Pennsylvania State University Press. 1998.

Murillo, Maria Victoria. Labour Unions, Partisan Coalitions and Market Reforms in Latin America. New York: Cambridge University Press. 2001.

Nichols, Theo and Nadir Sugur. Global Management, Local Labour. London: Palgrave Macmillan. 2004.

Onis, Ziya. "Inflation and Import-Substituting Industrialization: An Interpretation of the Turkish Case", Journal of Economics and Administrative Studies, vol.1, no.1, (1987).

Onis, Ziya. "The Dynamics of Export-Oriented Growth in a Second Generation NIC: Perspectives on the Turkish Case, 1980-1990", New Perspectives on Turkey, 9, (1993) 75100. https://doi.org/10.1017/S0896634600002223

Onis, Ziya. 'The Political Economy of Export-Oriented Industrialization in Turkey' in C. Karatas. et. al. (ed), Turkey: Political, Social and Economic Challenges during the 1990s. Leiden: Brill. 1995.

Onis, Ziya. and A. Faruk Aysan. "Neoliberal globalisation, the nation-state and financial crises in the semi-periphery: A comparative analysis." Third World Quarterly, vol.21, no.1 (2000), 119-139. http://www.jstor.org/stable/3993528

Onis, Ziya. and Fikret Senses. "Rethinking the Emerging Post Washington Consensus." Development and Change. Vol. 36, No. 2, (2004), 263-290. Doi: 10.1111/j.0012155X.2005.00411.X

Parla, Taha. "Mercantile Militarism in Turkey, 1960-1998" New Perspectives on Turkey. Vol.19, no.3 (1998), 29-52. https://doi.org/10.1017/S0896634600003010

Patroni, Viviana. "Structural Reforms and Labour Movement in Argentina" Labour, Capital and Society, vol.35, no.2, (2002), 252-280.

Patroni, Viviana. "Disciplining Labour, Producing Poverty: Neoliberal Structural Reforms 
and Political Conflict in Argentina.' In Neoliberalism in Crisis, Accumulation, and Rosa Luxemburg's Legacy

Research in Political Economy, Volume 21 (2004), 91-119.

Peters, Tom. Thriving on Chaos: Handbook for a Management Revolution. London: Macmillan. 1987.

Piore, Michael J. and Charles Sabel. The Second Industrial Divide: possibilities for prosperity. USA: Basic Books. 1984.

Polanyi, Karl. The Great Transformation. Boston: Beacon Press. 2001 (1944).

Ramos, Monica Peralta. La Economia Politica Argentina: Poder y Clases Sociales (19302006). Buenos Aires: Fondo de Cultura Economica. 2007.

Riquelme, Graciela. La Educacion Secundaria Antes y Despues de la Reforma. Buenos Aires: Mino y Davila. 2005.

Schneider, Ben Ross and David Soskice. "Inequality in developed countries and Latin America: coordinated, liberal and hierarchical systems", Economy and Society, vol.38, no.1, (2009), 17-52. http://dx.doi.org/10.1080/03085140802560496

Schorr, Martin. Industria y Nacion: Poder Economico, Neoliberalismo y Alternativas de Reindustrializacion En La Argentina Contemporanea. Buenos Aires: Edhasa. 2004.

Simons, Maarten. "Governmentality, Education and Quality Management", Zeitschrift fur Erziehungswissenschaft, vol.5, no.4, (2002), 617-633. Doi: 10.1007/s11618-002-0035-5

Simons, Maarten. "Learning as Investment: Notes on governmentality and biopolitics", Educational Philosophy and Theory, vol.38, no.4 (2006), 523-540. Doi: 10.1111/j.14695812.2006.00209.x

Simons, Maarten and Jan Maaschelein. (2006). "The Learning Society and Governmentality: An introduction", Educational Philosophy and Theory, vol.38, no.4, 417-430. Doi: 10.1111/j.1469-5812.2006.00202.x

Snyder, Richard. Politics After Neoliberalism: reregulation in Mexico. New York: Cambridge University Press. 2001.

Thelen, Kathleen. How Institutions Evolve: The Political Economy of Skills in Germany, Britain, the United States, and Japan. New York: Cambridge University Press. 2004.

Waterbury, John. "Export-Led Growth and the Center-Right Coalition in Turkey", Comparative Politics, vol.24, no.2, (1992), 127-145. doi:10.2307/422274

\section{Endnotes}

\footnotetext{
${ }^{1}$ The author would like to thank José Itzigsohn, Melani Cammett, Richard Snyder, Matthias vom Hau, Viviana Patroni, Fuat Keyman and the editorial board of SPE for very useful comments on this paper.
} 
${ }^{2}$ I borrow the term "discipline without punishment" from Grote 1995. This book claims to be "the proven strategy that turn problem employees into superior performers".

${ }^{3}$ Miozzo 2000, 657, Duruiz 1999.

${ }^{4}$ It must be added that during the first half of the 1990 s, the unemployment rate in both countries was at a similar level and remained below 10\% (Source: IMF World Economic Outlook). Beginning in the mid 1990s, unemployment rate in Argentina hit double digits while in Turkey it remained below 10\% until 2008. In that sense, the threat of unemployment was much higher in Argentina - together with fast-rising precarious work conditions - (Patroni 2004, 91) yet, this did not deter workers from taking a more contentious route. As we will see, workers in the Cordoba factory were unwilling to comply with proposed changes despite greater risk of unemployment.

${ }^{5}$ UOM is the acronym for Union Obrera Metalurgica and SMATA is the acronym for Sindicato de Mecanicos y Afines del Transporte Automotor.

6 "Bernar Nahum: Tofas'in Dogusu Gorkemli Oldu" (Bernar Nahum: The Birth of Tofas was Magnificient) Milliyet, September 28, 1988, p.9.

${ }^{7}$ TURKMETAL is the largest union organized in the metalworking and automobile industry. It was (and remains) a highly autocratic union under the leadership of Mustafa Ozbek, who held this position for over 25 years. TURKMETAL became exceptionally dominant in organizing the workers after the 1980 coup as rival unions were blacklisted and suspended by the military government. In its ideological orientation, it is very statist, center-right, nationalist and pro-business. For a more extended study on this union, see Nichols and Sugur 2004.

${ }^{8}$ Moreover, in both countries, these firms benefited from liberalized labour laws and could dismiss workers at a very low or no cost. For example, in Turkey, article 17 of the law no 1475 grants employers the right to terminate the contract when the worker engages in types of behavior that "goes against morals and good intentions". Similarly, in Argentina, labour law grants the employer to terminate a contract without severance pay if the worker exhibits "poor conduct" and under these circumstances, no severance pay is due. See: http://www.ilo.org/ifpdial/information-resources/national-labour-law-profiles/WCMS 158890/lang-en/index.htm for a general overview of Argentine labour law.

${ }^{9}$ Tolliday and Zeitlin 1986, 2-3.

${ }^{10}$ Rothstein 2006; Womack et.al. 2007.

${ }^{11}$ By "coercive apparatus", Foucault specifically refers to institutions of the modern prison system.

${ }^{12}$ See pp.170-194 in Foucault 1991 for a detailed discussion on the types of training Foucault refers to. In this work, Foucault specifically refers to regular exercises in prisons for developing good habits as a major tool for discipline under the coercive apparatus.

${ }^{13}$ Foucault, Discipline and Punish, 174.

${ }^{14}$ Foucault, Discipline and Punish, 181.

${ }^{15}$ Hayek (1944 and 1978) was one of the influential figures who laid down the theoretical underpinnings of neoliberalism. In this article, I adopt a definition of neoliberalism that conceptualizes it as a policy form: it refers to the gradual withdrawal of the state from regulating the economic domain in addition to cut-backs in social service provision.

${ }^{16}$ Deneault, Offshore, 31.

${ }^{17}$ See Onis and Aysan 2000; Patroni 2002; Onis and Senses 2005.

${ }^{18}$ In 1975, the first quality circle was formed in the US at the Lockheed Missiles and Space Company. On the other side of the Atlantic, when Thatcher launched the neoliberal slogan TINA (There Is No Alternative), the quality guru David Hutchins organized the first UK conference on Quality Circles (Hutchins 1985, 258).

${ }^{19}$ These new techniques of employee management were largely influenced by the organizational innovations implemented by the Toyota Corporation during the late 1960s. The diffusion of Toyotism-inspired personnel management techniques, including quality improvement methods, coincides with the promotion of neoliberal economic principles during the 1970s. For an analysis of Toyotism and its developmental phases see Gronning 1997.

${ }^{20}$ Hutchins, Quality Circles, 1.

${ }^{21}$ Hutchins, Quality Circles, 44.

${ }^{22}$ See also Crosby 1979, Peters 1987. According to Hutchins (1985) the principle of self-control includes problem solving and where possible, implementing solutions without the direct involvement of the management.

${ }^{23}$ Imai, Kaizen, 217 and Kelemen, Managing Quality, 127.

${ }^{24}$ These include firm-based welfare service provision i.e. private health insurance, scholarships for employee children, and discount purchases from the company coop.

${ }^{25}$ I thank José Itzigsohn for this point.

${ }^{26}$ Imai, Kaizen, 233-4

${ }^{27}$ Kelemen, Managing Quality, 135.

${ }^{28}$ Kelemen, Managing Quality, 135.

${ }^{29}$ Interview with worker RRL, Bursa, January 2008. 
${ }^{30}$ Althusser 2006.

${ }^{31}$ Hall and Soskice, Varieties of Capitalism.

${ }^{32}$ See the debate on the distinction between liberal market economies and coordinated market economies in

Hall and Soskice 2001.

${ }^{33}$ Iversen and Stephens 2008; Bosch and Charest 2008.

${ }^{34}$ For a comparison of national vocational education and training systems see Finlay et.al. 1998.

${ }^{35}$ Interview with HR Manager and Industrial Operations Manager, Bursa, November 21, 2007.

${ }^{36}$ For a detailed account of politically motivated economic conflicts in this city, see Turkiye Sendikacilik Ansiklopedisi, Vol. 3, pp. 247-250.

${ }^{37}$ Interview with former Industrial Opexrations Manager, Istanbul, November 29, 2007.

${ }^{38}$ See Ismet Akca (2006), "Militarism, Capitalism and the State: Putting the Military in Its Place in Turkey." Unpublished PhD Dissertation, Bogazici University; and Parla 1998.

${ }^{39}$ For an analysis of ISI policies in Turkey during the 1970s, see Onis 1987.

${ }^{40}$ For an analysis of transition to export oriented production in Turkey, see Onis 1995, 1993 and Waterbury 1992.

${ }^{41}$ Interview with former Industrial Operations Manager, Istanbul, November 29, 2009.

${ }^{42}$ For a brief analysis of restrictions on organized labour in Turkey see Haggard and Kaufman 1997. For a detailed analysis of labour policy in the post 1980 era see Boratav, Turel and Yeldan 1996 and Boratav 1990.

${ }^{43}$ Haggard and Kaufman 1997, 272.

${ }^{44}$ Interview with former Industrial Operations manager, Istanbul, November 29, 2007.

${ }^{45}$ Interview with former HR aide to the company, Istanbul, September 7, 2007.

${ }^{46}$ Interview with worker YNK, Bursa, January 2008.

${ }^{47}$ Interview with worker RSD, Bursa, January 2008.

${ }^{48}$ The crisis management policies of Tansu Ciller government in 1994 - particularly, her influence on the Central Bank in managing the currency exchange rate and monetary supply - were strongly rejected by the big business community, including the Koc-Fiat partnership.

${ }^{49}$ For an analysis on the impact of Customs Union on Turkish economy, see Mercenier and Yeldan 1997.

${ }^{50}$ Interview with the Industrial Operations Manager, Bursa. November 21, 2007 and January 15, 2008.

${ }^{51}$ Interview with the HR Manager, Bursa, December 26, 2008.

${ }^{52}$ Interview with the former Industrial Operations Manager, Istanbul, November 29, 2008.

${ }^{53}$ For example, a letter written by FIAT Bursa managers on 12.7.1994 asks the council to take necessary measures to reduce the number of vocational high school students to be trained on factory premises in order to make the training system more efficient and suggests the termination of credit based system because it keeps young trainees idle once they are done with the minimum required coursework.

${ }_{54}^{54}$ Apaydin 2012.

${ }^{55}$ See National Ministry of Education (2001), Total Quality System in Technical Education (MEB Teknik Egitimde Toplam Kalite Yonetimi) MEB: Ankara.

${ }^{56}$ Interview with Rahmi Ozyigit, Bursa Ekonomi Dergisi (Bursa Economy Journal), December 2007.

${ }^{57}$ Interview with Industrial Operations Manager (with the participation of the Human resources director), Bursa, November 21, 2008.

${ }^{58}$ Proposals include cost-cutting suggestions and process improvement drafts submitted by each individual worker as part of quality improvement program. Interview with Human Resources Director, Bursa, December $26^{\text {th }}, 2008$.

${ }^{59}$ Conversation with Industrial Operations Manager Assistant, Bursa, February 2008.

${ }^{60}$ In an earlier study, Nichols and Sugur (2004) also note an anti-union tendency among the workers of the same factory.

${ }^{61}$ Interview with worker RSD, Bursa, January 2008.

${ }^{62}$ Interview with worker NTK, Bursa, January 2008.

${ }^{63}$ For more information on this partnership, see http://hurriyetemlfiat.blogspot.com/

${ }^{64}$ Interview with the Industrial Director, Córdoba, May 5, 2008.

${ }^{65}$ Interview with former HR manager, Córdoba, June 17, 2008.

${ }^{66}$ Interview with Industrial Operations Manager, Córdoba, May 5, 2008.

${ }^{67}$ For example, see La Voz del Interior, August 21, 1973; August 25, 1973.

${ }^{68}$ For a detailed analysis of labour politics during this period, see Munck 1998.

${ }^{69}$ Ramos 2007; Patroni 2004; Schorr 2004; Murillo 2001

${ }^{70}$ Murillo, Labour Unions, 131.

${ }^{71}$ For a detailed analysis of this period, see Ramos 2007, 231-255.

${ }^{72}$ For an overview of Alfonsin's economic policy see Ramos 2007, 230.

${ }^{73}$ See Murillo, Labour Unions, 156. The decree 2677/91 marks the beginning of the special regime for the automobile production in Argentina. For a detailed analysis of this policy see Barbero and Motta 2007. As a result of this policy, the export shares of automobiles in Argentina rose dramatically. The automobile exports 
of international firms located in this country increased by 1,063\% between 1991 and 1998, representing a total share of $36 \%$ of total industrial exports. See Ramos 2007, 325 .

${ }^{74}$ For example, one of the goals of decentralizing the education was "respond to the demands to prepare for the professional life, considering the future active insertion of the youth into the changing world of work that becomes more competitive each time" (Riquelme 2005: 181).

${ }^{75}$ Interview with Eduardo Angeloz, Córdoba, July 24, 2008.

${ }^{76}$ Interview with Eduardo Angeloz, Córdoba, July 24, 2008.

${ }^{77}$ Interview with Eduardo Angeloz, Córdoba, July 24, 2008.

${ }^{78}$ For a detailed analysis of the impact of decentralization of education in Córdoba see Ferreyra 2006. For a comparison of the impact of decentralization across Argentina, see Riquelme 2005. For Angeloz's position on the decentralization of education, see Falleti 2004. Financial difficulties deepened by the political crisis between Córdoba and Buenos Aires is one major reason why revamping vocational education curricula was not a priority for the Angeloz and Mestre governments. Without public agencies covering the bulk of the costs of training, private sector did not have any interest in pushing the agenda further and focused on firm-based trainings instead.

${ }^{79}$ For an analysis of partisan alliances between the SMATA and the PJ, see Murillo 2001, 155-157.

${ }^{80}$ La Voz del Interior, September 27, 1995; November 1, 1995 and February 10, 1996.

${ }^{81}$ At the end of the trial process, Angeloz was cleared of all the charges.

${ }^{82}$ Interview with Eduardo Angeloz, Córdoba, July 242008 and also see La Voz del Interior, June 24, 1995.

${ }^{83}$ La Voz del Interior, March 4, 1997 and May 10, 1998.

${ }^{84}$ La Voz, del Interior, July 16, 1995; December 19, 1995; September 11, 1996; December 21, 1996; Feb 21, 1997; April 16, 1997; April 20, 1997 and May 28, 1997,

${ }^{85}$ La Voz del Interior, November 30, 1995; July 18, 1996 and June 4, 1998.

${ }^{86}$ La Voz del Interior. September 20, 1996, September 23, 1996, January 23, 1997; January 24, 1997 and January 25, 1997.

${ }^{87}$ Interview with former shopfloor leader, Córdoba, July 31, 2008.

${ }^{88}$ Interview with former shopfloor leader, Córdoba, July 31, 2008.

${ }^{89}$ La Voz del Interior, September 28, 1996.

${ }^{90} \mathrm{La} \mathrm{Voz} \mathrm{del} \mathrm{Interior,} \mathrm{January} \mathrm{31,} 1997$.

${ }^{91}$ Interview with former HR Manager, Córdoba, June 17, 2008.

${ }^{92}$ Interview with former HR Manager, June 17, 2008.

${ }^{93}$ Interview with worker, Córdoba, June 18, 2008.

${ }^{94}$ La Voz del Interior, May 26, 1997.

${ }^{95} \mathrm{La}$ Voz del Interior, December 30, 1997.

${ }^{96} \mathrm{La}$ Voz del Interior, December 4, 1998.

${ }^{97}$ Blind 2009.

${ }^{98}$ Collier and Mahoney 1997.

${ }^{99}$ For a conversation with Foucault on governmentality see Burchnell et.al. 1991. For a discussion on the link between state, governmentality and education policies see Edwards 2002, Simons and Masschelein 2006, McCarthy and Dimitriadis 2000, Kivinen and Rinne 1998. 